\title{
SUSTAVI DIJELJENJA VOŽNJI U FUNKCIJI SMANJENJA PROMETNIH ZAGUŠENJA UZ ZADRŽAVANJE DOSTIGNUTE RAZINE MOBILNOSTI STANOVNIŠTVA ${ }^{4}$
}

\section{SAŽETAK}

Neosporne prednosti automobila u pogledu udobnosti i neovisnost koje pruža, odnosno fleksibilnost kretanja i mogućnost prilagodbe potrebama pojedinih korisnika, dovele su do visoke stope motorizacije i nepoželjnog fenomena „o autu ovisnih“ društava. Posljedično, upravo zbog pretjerane uporabe osobnih automobila is tim povezanih prometnih zagušenja, gube se njegove navedene prednosti, uz niz drugih nepovoljnih efekata. Prometna zagušenja smanjuju brzinu kretanja vozila i produžuju vrijeme putovanja, izazivaju stres inervozu kod vozača, smanjuju sigurnost prometa te dovode do povećane emisije štetnih plinova, odnosno zagađenja okoliša. Jedan od načina umanjenja navedenih posljedica racionalnija je uporaba osobnih vozila, koja se može postići, između ostalog, primjenom sustava dijeljena vožnji. Sustav carpooling funkcionira na principu uzajamne koristi vozača i putnika (vozaču osigurava smanjenje troškova, a putnik koristi sve prednosti osobnog automobila) te doprinosi povećanju broja putnika u vozilu dok carsharing omogućuje dostupnost vožnje automobilom svim osobama koje imaju vozačku dozvolu, bez potrebe posjedovanja osobnog vozila. Prema tome, ovi sustavi omogućuju reduciranje broja vozila u prometu, a time i smanjenje svih nepovoljnih efekta uz zadržavanje, gotovo u potpunosti, svih prednosti korištenja osobnog automobila. Prema provedenom anketnom istraživanju, u Republici Hrvatskoj postoji značajan interes za korištenje ovakvih sustava odnosno usluga.

Ključne riječi: carpooling, carsharing, dijeljena vožnja, mobilnost

\section{UVOD}

Velika emisija štetnih plinova, zagušenja u prometu i potrošnja neobnovljivih izvora energije samo su neke od negativnih posljedica kontinuiranog razvoja cestovnog prometa. Navedeno pobuđuje stalni interes stručnjaka i znanstvenika, ali i svih sudionika prometnog procesa koji primjenom različitih strategija i politika održivog razvoja nastoje umanjiti negativan utjecaj visokog stupnja motorizacije, ne umanjujući pritom razinu mobilnosti stanovništva.

Razne restrikcije u vidu ograničavanja pristupa automobilom, visokih poreza na gorivo, visokih cijena parkinga i naknada za ulazak u centar grada, bez osiguravanja alternativne mobilnosti, ne 
mogu dovesti do željenog cilja, odnosno eliminiranja suviše intenzivnog korištenja osobnih vozila u svakodnevnom životu građana.

Politike odvraćanja od korištenja automobila mogu biti djelotvorne samo ako se kombiniraju sa strategijama koje potiču javni prijevoz, poput pješačenja i biciklizma, ali i racionalniju upotrebu osobnih vozila, iz čega proizlazi glavni cilj rada: istražiti utjecaj sustava dijeljena vožnji na negativne posljedice nastale pretjeranom uporabom osobnih vozila i mogućnosti uvođenja sustava dijeljena vožnji u Republici Hrvatskoj. Provedenim istraživanjem testirana je sljedeća hipoteza: razvoj sustava dijeljene vožnje posjeduje značajan potencijal u pogledu željenog smanjenja prometnih zagušenja i drugih s njim povezanih negativnih utjecaja uz zadržavanje visoke razine mobilnosti stanovništva.

$\mathrm{S}$ ciljem testiranja navedene hipoteze, osim analize dostupne literature, provedeno je i online anketno istraživanje kojim je testirana zainteresiranost potencijalnih korisnika za korištenje sustava dijeljena vožnji u Republici Hrvatskoj te razlozi, kao i učestalost korištenja usluge carpoolinga (u vrijeme provedbe anketa usluga carsharing nije bila dostupna široj populaciji).

\section{POSLJEDICE RAZVOJA CESTOVNOG PROMETA}

Ozbiljniji razvoj automobilske industrijezapočeo jeznatno prije uSAD-u nego u ostatku svijeta. Američki proizvođači automobila od samog su početka orijentirani na stvaranje jeftinog, standardiziranog vozila koje će biti dostupno većem broju kupaca, što je kulminiralo linijskom proizvodnjom i čuvenim Fordovim modelom - T. Niska cijena, a time i dostupnost širokom krugu stanovništva, rezultirali su visokim stupnjem motorizacije te već 1920 . godine gotovo petina Amerikanaca ima motorno vozilo (Katz, 2012:4). Nastavak tog trenda pretvorio je Ameriku u sinonim o automobilima ovisnog društva, no val motorizacije nakon II. svjetskog rata zahvatio je i Europu i ostatak razvijenog svijeta.

Neosporne prednosti automobila u pogledu udobnosti i neovisnosti koje pruža korisnicima, fleksibilnost kretanja i mogućnost prilagodbe potrebama dovele su do kontinuiranog rasta i njegove pretjerane uporabe. U 2014. godini za čak $83 \%$ ostvarenih putničkih kilometara na području 28 zemalja Europske unije korišten je osobni automobil (tablica 1). Iz iste tablice može se uočiti sličan trend i na području Republike Hrvatske, pri čemu se, s gospodarskim razvojem, može očekivati daljnje povećanje uporabe automobila jer „bez iznimke u svakoj bivšoj socijalističkoj zemlji u Srednjoj i Istočnoj Europi politički i gospodarski pomak proizveo je odgovarajuću prijevoznu revoluciju čiji je najočitiji pokazatelj dramatičan rast u razini privatnog vlasništva automobila“ (Pucher, Buehler, 2005:725). 
Tablica 1. Postotak udjela pojedine vrste prijevoza u putničkim kilometrima u razdoblju od 2012. do 2014. godine u Europi

\begin{tabular}{|l|l|c|c|c|c|c|c|c|c|}
\hline \multirow{2}{*}{ Lokacija / godina } & \multicolumn{4}{|c|}{2012.} & \multicolumn{3}{c|}{2013.} & \multicolumn{3}{c|}{2014.} \\
\cline { 2 - 10 } & 1 & 2 & 3 & 1 & 2 & 3 & 1 & 2 & 3 \\
\hline EU (28 zemalja) & 83 & 9,3 & 7,7 & 83,2 & 9,3 & 7,6 & 83,4 & 9,1 & 7,6 \\
\hline EU (27 zemalja) & 83 & 9,3 & 7,7 & 83,2 & 9,2 & 7,6 & 83,3 & 9,1 & 7,6 \\
\hline Njemačka & 85,4 & 5,7 & 8,9 & 85,8 & 5,7 & 8,5 & 85,7 & 6,9 & 8,5 \\
\hline Francuska & 85,1 & 5,4 & 9,6 & 85,1 & 5,5 & 9,4 & 85,1 & 5,6 & 9,3 \\
\hline Hrvatska & 79,6 & 10,7 & 3,5 & 80,5 & 11,5 & 3,1 & 80,8 & 11,9 & 3 \\
\hline
\end{tabular}

1 - osobni automobili; 2 - autobusi i tramvaji; 3 - vlak

Izvor: obrada autora prema podacima dostupnim na poveznici http://ec.europa.eu/eurostat/statistics-explained/ index.php/Passenger_transport_statistics (13.1. 2017.)

Ovakav rast vlasništva i korištenja automobila posljedica je vjerovanja i prometnih politika 60ih i 70-ih godina prošlog stoljeća da se radi o prijevoznim sredstvima budućnosti. Relativno brzo se spoznala zabluda te je posljednjih desetljeća upravo ovisnost o automobilu identificirana kao pitanje od najveće važnosti za prometne planere, zbog njenog velikog negativnog gospodarskog i društvenog utjecaja. Naime, ovisnost o automobilu modernog svijeta jedan je od glavnih uzroka zagušenja i drugih negativnih učinaka, poglavito u pogledu zaštite okoliša i potrošnje neobnovljivih resursa.

Osim zagađenja okoliša, jedan od osnovnih problema nastalih pretjeranim korištenjem osobnih vozila su i gužve u prometu koje su posebno izražene u vršnim satima. $U$ većini europskih gradova i država za više od 50 \% putovanja na posao koristi se upravo osobno vozilo. Izuzetak su uglavnom najveći gradovi (metropole) ili njihovi uži centri, i zbog vrlo kvalitetnog javnog gradskog prometa i zbog primoranosti stanovništva na njegovo korištenje, zbog uvjeta u cestovnom prometu, odnosno zagušenja (grafikon 1). Prema podacima objavljenim na stranicama statističkog ureda Europske unije (Eurostata) u 2015. godini prosječno izgubljeno vrijeme u prometu u Londonu iznosilo je 101 sat; London su slijedili Stuttgart s izgubljena 73 sata te Antwerpen i Köln s prosječno izgubljenim 71 satom. “Prosječna brzina auto putovanja svega je 10-15 km/h u gradovima kao što su London, Pariz, Tokyo, Jakarta, Teheran ili Mexico sa sličnim vrijednostima u gotovo svim drugim gradovima svijeta koji su suočeni s teškim zagušenjima na cestama" (Mohan, 2009:4). U svakom slučaju zagušenja u prometu znatno produljuju vrijeme putovanja, ograničavaju mobilnost, uzrokuju stres kod vozača, povećavaju opasnost od prometnih nesreća, a samim time dovode u pitanje i osnovne prednosti uporabe osobnih vozila koje se očituju kroz fleksibilnost kretanja i komfor vožnje. 
Grafikon 1. Prikaz korištenja pojedinih oblika transporta kod odlazaka na posao

u 2011. godini u većim gradovima Europske unije

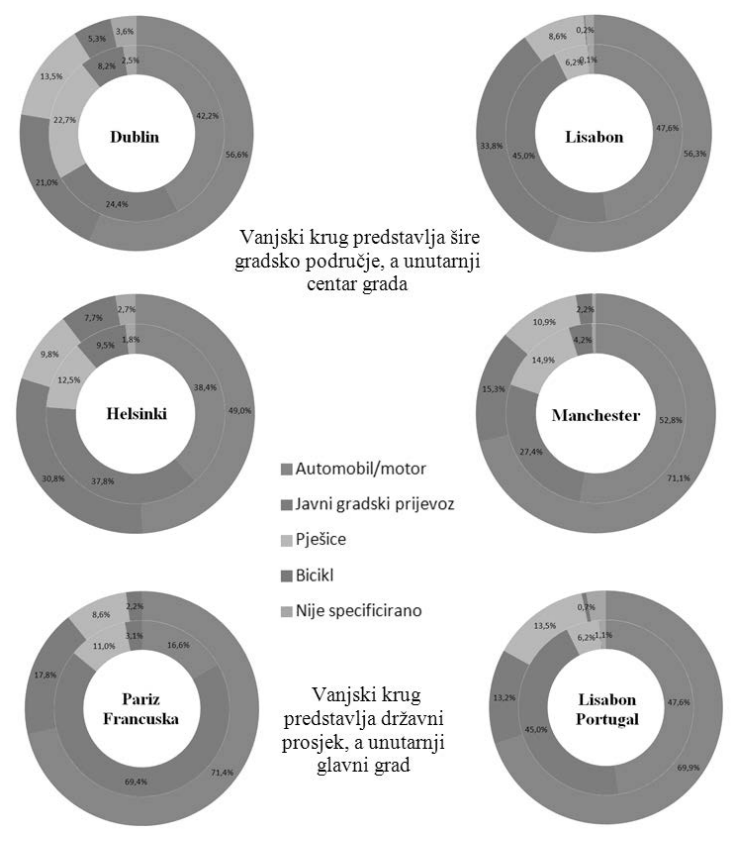

Izvor: obrada autora prema podacima dostupnim na poveznicama http://appsso.eurostat.ec.europa.eu/nui/ submitViewTableAction.do i http://ec.europa.eu/eurostat/documents/3217494/7596823/KS-01-16-691-EN-N. pdf/0abf140c-ccc7-4a7f-b236-682effcde10f (p. 189) (27. 1. 2017.)

Dakle, visoke stope motorizacije ili, bolje rečeno, „automobilska ovisnost“ vrlo je nepoželjan fenomen za gradove i život u njima te predstavlja jedan od fokusa interesa urbanog i prometnog planiranja. Politike i strategije koje se koriste za rješavanje ovog problema uglavnom se temelje na odvraćanju stanovništva od korištenja automobila za putovanje unutar grada, npr. nametanjem odredbi koje ograničavaju pristup automobilom, politikom cijena (visoki porez na gorivo i vlasništvo automobila, cijena parkinga), zabranom prometa automobilima u središnjim gradskim područjima i/ili nametanja visokih naknada za parking i ulazak u zakrčene dijelove grada itd. No odvraćanje od korištenja automobila samo po sebi ne može dovesti do željenog cilja, odnosno, putnicima se mora osigurati alternativna mobilnost. Politike odvraćanja mogu biti djelotvorne samo ako su u kombinaciji sa strategijama koje promiču javni prijevoz, biciklizam, pješačenje, ali i racionalizaciju, uporabe automobila, npr. kroz sustave dijeljenja vožnji ili vozila.

\section{SUSTAVI DIJELJENJA VOŽNJI}

Pod dijeljenjem vožnje podrazumijeva se zajedničko putovanje dviju ili više osoba do određene destinacije tako da svi suputnici ravnopravno dijele troškove vožnje (carpooling) ili korištenje vozila organizacije koja posjeduje određeni broj osobnih automobila te nudi korisnicima mogućnost 
njihova korištenja pod određenim uvjetima (carsharing). Način naplate i općenito korištenja razlikuje se ovisno o organizaciji. 2016. godine Calvert i Chatterjee izvršili su analizu četrnaest studija koje su pokrivale tematiku carpoolinga i carsharinga na području Europe i Sjeverne Amerike. lako su studije najčešće rađene na ograničenim prostorima, poput grada ili područja određene države, zaključci do kojih se došlo tijekom istraživanja mogu se primijeniti bilo gdje, pa su korišteni kao baza za izradu ovog članka.

\section{1 Carpooling}

Proučavajući termin carpooling u literaturi može se zaključiti da se koncept ne temelji nužno na dogovoru znanaca, već se spomenuti termin odnosi na sve dijeljene vožnje u privatnom vozilu općenito, neovisno o prethodnom poznanstvu suputnika (Handke, Jonuschat, 2013:13).

Carpooling postoji u dva osnovna oblika: planirani i dinamički. Planirani carpooling, kao što i sam naziv govori, planira se unaprijed putem dostupnih internetskih stranica ili aplikacija. Nakon pronalaska carpool partnera, slijedi dogovor u vezi s detaljima vožnje kao što su cijena putovanja, lokacija polaska te dogovor oko ostalih detalja (Créno, 2014:2). Osim internetskih portala i mobilnih aplikacija suputnici se za planirani carpooling pronalaze i dogovorom poznanika. Dinamički, odnosno stvarnovremenski carpooling omogućuje potencijalnim korisnicima da uslugu te vrste prijevoza iskoriste bez prethodnog dogovora, već neposredno u tom trenutku kad im je vožnja potrebna, tako da, primjerice, mobilnom aplikacijom koja koristi GPS, pronađu osobu koja ima rutu putovanja kakvu oni žele i vide gdje se ta osoba nalazi. Na taj način pronađu vozača koji se nalazi u njihovoj blizini i voze u smjeru u kojem oni žele ići. Ako to nije moguće, tj. ako nitko ne nudi prijevoz do njihove željene destinacije iz njihove blizine, preostaje im da zatraže prijevoz dokud žele te, ako netko ide u tom smjeru, javi njima.

Correia i Viagas te Chan i Shaheen kao problem sustava carpooling istaknuli su njegovu nefleksibilnost. Korisnici koji se odluče na takav vid vožnje tijekom putovanja više ne mogu promijeniti njegovu destinaciju. Osim toga, istaknuli su i problem u vidu neželjenih socijalnih interakcija među korisnicima te vrijeme koje je potrebno da vozač prikupi sve zainteresirane sudionike, što produžava ukupno trajanje putovanja i povećava broj prijeđenih kilometara.

Za primjenu sustava carpooling nužno je uspostavljanje povjerenja među korisnicima sustava. Sjedanje u automobil s nepoznatim vozačem opravdano stvara osjećaj nesigurnosti te se javlja otpor prema navedenom obliku prijevoza. Servisi koji imaju mogućnost anonimnog ocjenjivanja korisnika sustava mogu pridonijeti povećanju kvalitete pružene usluge te umanjiti strah od nepoznatog. Navedeni je problem također moguće riješiti ako se $u$ ovakav sustav dijeljene vožnje uključe zaposlenici, studenti ili kolege koji se međusobno poznaju i žele smanjiti troškove uzrokovane uporabom osobnih vozila. Osiguranjem posebnih parkirnih mjesta za korisnike sustava carpooling, razne tvrtke, sveučilišta, veleučilišta i slične organizacije mogu poticati primjenu sustava dijeljenja vožnji na svojim područjima.

Ipak, sustav carpooling ima i određene prednosti. Primjena sustava smanjuje troškove upotrebe osobnih automobila te nudi beneficije u smislu korištenja povlaštenih parkirnih mjesta i posebnih prometnih traka - HOVs traka - namijenjenih vozilima s više od jednim putnikom. 
Zbog korištenja HOV traka u Washingtonu se razvio još jedan oblik carpoolinga - instant ili casual carpooling koji se najčešće u američkom slengu naziva slugging. Slugging se bazira na principu uzajamne koristi vozača i putnika. Vozaču su potrebni putnici za vožnju bržom trakom, a putnicima je potreban prijevoz. Zbog te uzajamne koristi tu uslugu vozači ne naplaćuju. Putnici se prikupljaju na predviđenim mjestima, tzv. slugg linijama, gdje vozači jednostavno izlože natpis kamo idu ili izvikuju to mjesto iz auta. Kad potencijalni putnici vide ili čuju željenu destinaciju, sjednu u automobil (http://www.slug-lines.com/slugging/About_ Slugging.asp, 15. 12. 2016.).

O sve većoj popularnosti carpoolinga u Hrvatskoj, poglavito među mlađom populacijom, svjedoči čitava bujica web-stranica i aplikacija koje omogućuju pronalazak vozača do željene destinacije ili mogućnost ponude vožnje. Isto su tako i društvene mreže preplavljene carpooling grupama. Tri popularna (i besplatna) servisa za navedeno su: ajmo.hr, oglasnik prijevoza te BlaBlaCar.

Primjena sustava carpooling u svakom slučaju povećava broj putnika po vozilu i može, u određenoj mjeri, smanjiti zagušenja u prometu, emisiju štetnih plinova i potražnju za brojnim parkirnim mjestima. No postoji i opasnost od povećanja broja prijeđenih kilometara te smanjenja broja korisnika javnog gradskog prometa, ako oni odluče iskoristiti prednosti koje nudi korištenje automobila.

\section{2 Carsharing}

U stručnoj literaturi nailazi se na različite definicije carsharinga, a često se spominje i kao sinonim carpoolingu, što dovodi do zablude. Naime, i carpooling i carsharing kao pojmovi označavaju tzv."dijeljenje automobila" pod određenim uvjetima, no kod carsharinga, za razliku od carpoolinga, vozilo nije u vlasništvu ni jednog putnika. Točnije, termin carsharing obuhvaća otvoreni pristup programu dijeljenih vozila koja su namijenjena za povremena putovanja automobilom (Murray et al., 2005:2).

Kao i u slučaju carpoolinga, postoje i dvije vrste sustava carsharing. Jedan je stacionaran i kod njega je unajmljeno vozilo potrebno vratiti na parkirno mjesto s kojeg je preuzeto te se stoga najčešće koristi za kružna putovanja. Slobodni carsharing sustav je praktičniji i može se koristiti i za jednosmjerna putovanja, jer je vozilo moguće ostaviti na više lokacija unutar zone primjene ovakvog sustava dijeljene vožnje.

U Europi broj korisnika sustava carsharing ubrzano raste. 2005. evidentirano je 75.000 korisnika, a u 2015. godini je taj broj premašio dva milijuna (Calvert, Chatterjee, 2016:172).

Sustav carsharing omogućuje dostupnost vožnje automobila svim osobama koje posjeduju vozačku dozvolu, a koje iz nekog razloga nisu u mogućnosti ili ne žele posjedovati vlastiti automobil. Time se direktno utječe na mobilnost građana i povećanje kvalitete života. Isto tako, carsharing se pojavljuje kao dobra opcija kućanstvima koja posjeduju jedan, a samo povremeno imaju potrebu koristiti više automobila. U takvom slučaju kupnja novog automobila predstavlja dodatni nepotrebni trošak, a problem je moguće riješiti primjenom carsharinga. Kao jednu od dodatnih prednosti primjene sustava carsharing Calvert i Chatterjee ističu mogućnost odabira 
među različitim veličinama vozila u ovisnosti o trenutnoj potrebi. Osim toga, korisnici sustava carsharing nemaju troškove održavanja i popravaka osobnih automobila.

Martin i Shaheen zaključili su da korisnici sustava carsharing zbog uštede u troškovima najma vozila koriste racionalnije, odnosno koriste vozilo rjeđe, prevaljujući pritom kraće udaljenosti. Prema istraživanju koje je 2012. godine provela Međunarodna agencija za energetiku (IEA) korisnici koji se pridruže carsharing sustavu godišnje prijeđu gotovo $5.000 \mathrm{~km}$ manje (Calvert, Chatterjee, 2016:175). Navedeno, uz pretpostavku da se dijeljeno vozilo tijekom dana koristi češće, odnosno da su razmaci među uporabama vozila značajno kraći nego kod osobnih automobila te da ne dolazi do hlađenja motora, uvelike smanjuje emisiju štetnih plinova, a samim time i zagađenje okoliša.

Cervero i Tsai 2004. godine procijenili su da 74 vozila namijenjena sustavu carsharinga s područja na kojem organizacija djeluje uklanjaju više od 500 osobnih vozila. Još su optimističnije procjene švedske organizacije Ecoplana iz 2012. čije istraživanje sugerira da jedno dijeljeno vozilo zamjenjuje deset do petnaest osobnih automobila. Osim toga, više autora je došlo do zaključka da korisnici sustava carsharing češće pješače ili koriste bicikl ili javni gradski prijevoz. Ter Schure, Napolitan i Hutchinson uspoređivali su navike korisnika sustava carsharing u odnosu na vozače kojima takva usluga nije na raspolaganju. 83 \% ispitanika koji su korisnici sustava carsharing za odlazak na posao koriste opcije koje ne uključuju automobile (bicikl, pješačenje). U sredinama u kojima navedena usluga nije na raspolaganju postotak iznosi $70 \%$. Osim toga, $43 \%$ korisnika odlučuje se na upotrebu javnog gradskog prometa. Ako usluga carsharinga nije dostupna, taj postotak iznosi samo 23 \% (Calvert, Chatterjee, 2016:176).

Važno je istaknuti da carsharing služi kao dopuna postojećem javnom gradskom prijevozu, te da on nije nužno zamjena za posjedovanje osobnog automobila. Naravno, sve ovisi o razlozima posjedovanja osobnog automobila. lako u odnosu na pješačenje i bicikliranje carsharing sustav ima negativne utjecaje na okoliš (postoji opasnost od prometnih nesreća, a buka i emisije štetnih plinova, osim u slučaju uporabe električnih vozila, i dalje postoje), navedeni utjecaji daleko su manji jer primjena ovog sustava dovodi do smanjenja prijeđenih kilometara i smanjenja broja vozila na cestama, a samim time i do smanjenja gužvi u prometu. Pritom korisnici i dalje uživaju u svim prednostima koje inače nudi posjedovanje osobnog vozila (komfor vožnje i fleksibilnost kretanja) te se može reći da primjena sustava carsharing pridonosi povećanju mobilnosti uz ublažavanje posljedica koje ubrzan razvoj cestovnog prometa sa sobom donosi.

\section{ISTRAŽIVANJE STAVOVA POTENCIJALNIH KORISNIKA SUSTAVA DIJELJENA VOŽNJI U RH}

Kako bi se dobili određeni pokazatelji o carpoolingu i carsharingu na području RH, provedeno je istraživanje, odnosno anketa na uzorku od 183 osobe. Anketno istraživanje provedeno je u okviru pisanja završnog rada studentice Prometnog odjela Veleučilišta u Rijeci te veličina uzorka predstavlja ograničavajući faktor. Stoga je za nedvosmislenu potvrdu iznesenih zaključaka u radu potrebno provesti dodatno, obuhvatnije istraživanje. 
Cilj istraživanja bio je saznati koliko je uopće ispitanika upoznato $s$ terminima carpooling $\mathrm{i}$ carsharing, koriste li carpooling (carsharing u vrijeme provedbe ankete u RH nije bio na raspolaganju široj populaciji, već samo zatvorenom krugu korisnika), te, ako ne koriste sustav, bi li postali korisnici. Osim toga, cilj je bio saznati neke relevantne stavove i mišljenja potencijalnih i aktualnih korisnika o tim temama.

Svi ispitanici imaju završeno srednjoškolsko ili visokoškolsko obrazovanje; istraživanjem nisu obuhvaćeni malodobni učenici jer oni nisu značajni potencijalni korisnici carpoolinga i carsharinga; carpoolinga pretežito zbog sigurnosnih razloga, posebice ako se radi o vožnji s nepoznatim ljudima, a carsharinga zbog neposjedovanja vozačke dozvole.

Najveći broj ispitanika mlađi je od 46 godina, što je posljedica načina provođenja ankete, ali i motiviranosti, odnosno vjerojatnosti korištenja ovih načina prijevoza. Posljedično, najveći broj ispitanih su učenici, studenti i zaposlene osobe, čak 171 od 183 ispitanika (93,4 \%). Preostali ispitanici su nezaposlene osobe, a umirovljenici ovim istraživanjem gotovo nisu obuhvaćeni (samo jedan ispunjen anketni upitnik). Potonje je rezultat načina provođenja ankete (internet) i predstavlja određenu manjkavost anketnog uzorka, jer su umirovljenici također potencijalni korisnici osobito carpoolinga, ali i carsharinga.

$U$ vezi s očekivanjima kako je jedna od važnih odrednica korištenja ovog načina prijevoza troškovna povoljnost, ispitanici su upitani i za visinu svojih mjesečnih primanja. Oko 2/3 ispitanika nema mjesečnih primanja ili su ona vrlo mala, ispod 3.000 kuna. Navedeno predstavlja ograničenja u tumačenju rezultata ankete jer očekivano mlađe osobe (studenti), kao i osobe nižih primanja, ne posjeduju automobile te time mogu biti više zainteresirani za ovaj način prijevoza. Najveći broj ispitanika, njih 72 (39,3\%), iako ima vozačku dozvolu, nisu vlasnici automobila, te ga imaju samo ponekad na raspolaganju. S druge strane, uvažavajući činjenicu da 66 ispitanika ( $36 \%$ ) posjeduje automobil i ima ga na raspolaganju (uvijek ili ponekad), ovaj se uzorak može smatrati reprezentativnim.

Razmatrajući strukturu ispitanika zaključujemo da nije iznenađujući relativno visok postotak ispitanika kojima su ovi, ipak ne tako uobičajeni, pojmovi poznati. $S$ druge strane, očit je i potencijal dodatne promidžbe jer od 183 ispitanika $56(30,6 \%)$ ispitanika nije nikada čulo za te termine. Najveći broj ispitanika s tim pojmovima upoznao se internetom, a neusporedivo manje njih navodi da je za njih čulo od poznanika. Neznatan broj ispitanika odgovorio je na prethodno pitanje da su za navedeno čuli posredstvom medija ili nekog drugog načina koji nije povezan $\mathrm{s}$ internetom (obrazovanje i sl.). Iz navedenog se može zaključiti kako je dio populacije koji se ograničeno ili uopće ne služi internetom zanemaren, što definira smjer $i$ mogućnost daljnje promidžbe i razvoja ove usluge. 
Grafikon 2. Odgovori ispitanika na pitanje jesu li koristili usluge carpoolinga

Count of Jeste li ikada koristili carpooling?

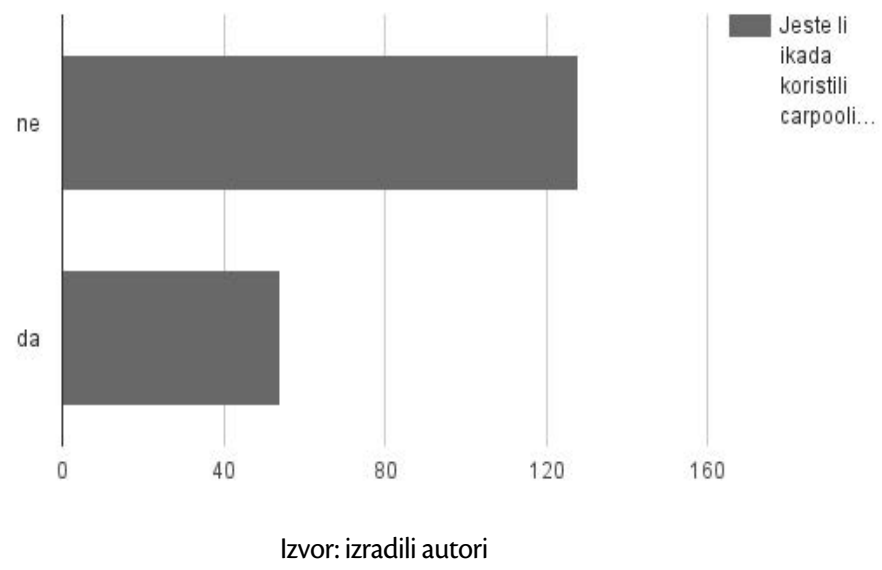

Relativno velik broj ispitanika koji su upoznati s uslugom carpoolinga koristili su ga (oko $50 \%$ ), tj. 54 ispitanika (grafikon 2 -29,5\%). No većina uslugu koristi vrlo rijetko. Najviše ispitanika koristi carpooling povremeno ( 47 od 54 ispitanika ( $87 \%$ )) dok 5 ispitanika (9,3\%) uslugu koristi 2 do 3 puta tjedno, a tek 2 (3,7 \%) jednom tjedno ili uvijek (grafikon 3). Prema tim podacima može se zaključiti da se carpooling pretežno koristi za neka povremena putovanja, vjerojatno na duže relacije, pri čemu su značajnije financijske uštede. Uvažavajući prethodno obrazloženi cilj smanjenja gužvi na cestama, posebice tijekom vršnih sati, jasno je kako je neophodno putnike potaknuti na korištenje carpoolinga prilikom svakodnevnih migracija (posao, fakultet i sl.), što za sad nije dovoljno čest slučaj u RH.

Grafikon 3. Struktura korisnika carpoolinga prema učestalosti korištenja te usluge

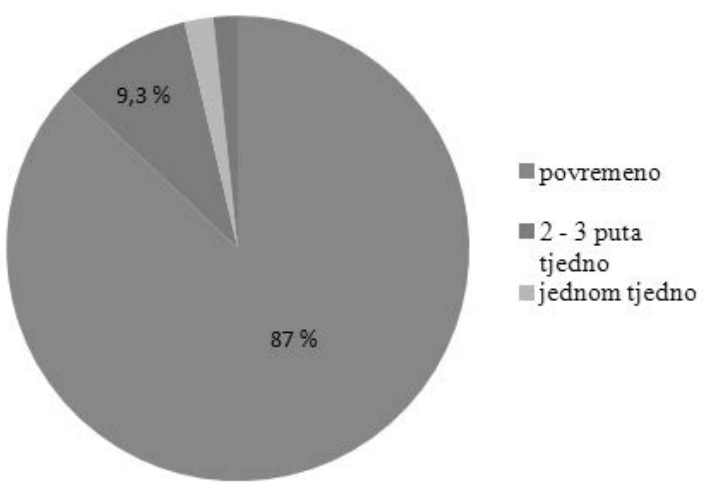

Izvor: izradili autori 
Ovakvi rezultati pokazuju kako često potencijalni i aktualni korisnici koji su upoznati s tim načinom prijevoza pogrešno smatraju da je on primjenjiv samo prilikom duljih relacija putovanja, npr. iz jednog grada u drugi, a zanemaruju činjenicu da carpooling funkcionira i prilikom prijevoza unutar jednog grada. Takvom shvaćanju pridonose internetski portali za tu namjenu te društvene mreže na kojima se uglavnom može naći prijevoz samo za dulje relacije (od grada do grada).

Najveći broj korisnika carpooling koristi već 3 - 5 godina, a visoki postotak njih i više od pet godina (grafikon 4). Ti rezultati pokazuju da je carpooling kao način prijevoza prisutan u Republici Hrvatskoj već duže vrijeme, isto kao i zadovoljstvo korisnika ovim načinom prijevoza.

Grafikon 4. Struktura korisnika carpoolinga prema godinama korištenja navedene usluge

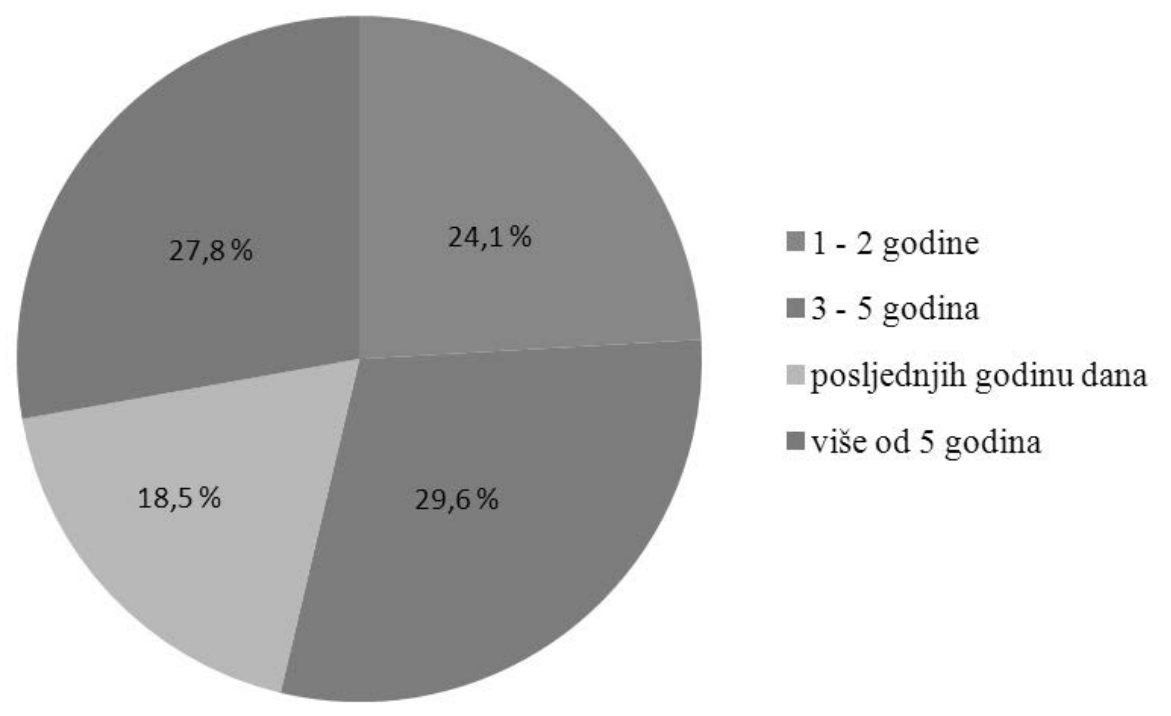

Izvor: izradili autori

Ono što dodatno ohrabruje i ukazuje na potencijal razvoja je činjenica da od 129 ispitanika koji nisu nikada koristili carpooling (70,5 \%) samo se 19 (14,7\%) izjasnilo da uslugu ne bi koristilo u budućnosti (grafikon 5). Razlozi nezainteresiranosti za korištenje usluge individualni su, a mogu proizlaziti iz još uvijek nedovoljnog znanja i prihvaćenosti u široj javnosti. Ipak, može se pretpostaviti kako je jedan od vodećih razloga za negativan stav prema tom obliku prijevoza činjenica da pojedincima vožnja s nepoznatim ljudima stvara nelagodu. Stoga, očekivano, u provedenoj anketi visok postotak ispitanika koji su se izjasnili da ne bi postali korisnici carpoolinga ( 14 od 19 ispitanika (73,7 \%)) osjeća nelagodu pri pomisli na vožnju s nepoznatim ljudima. 
Grafikon 5. Odgovori ispitanika na pitanje: Biste li postali korisnici carpoolinga?

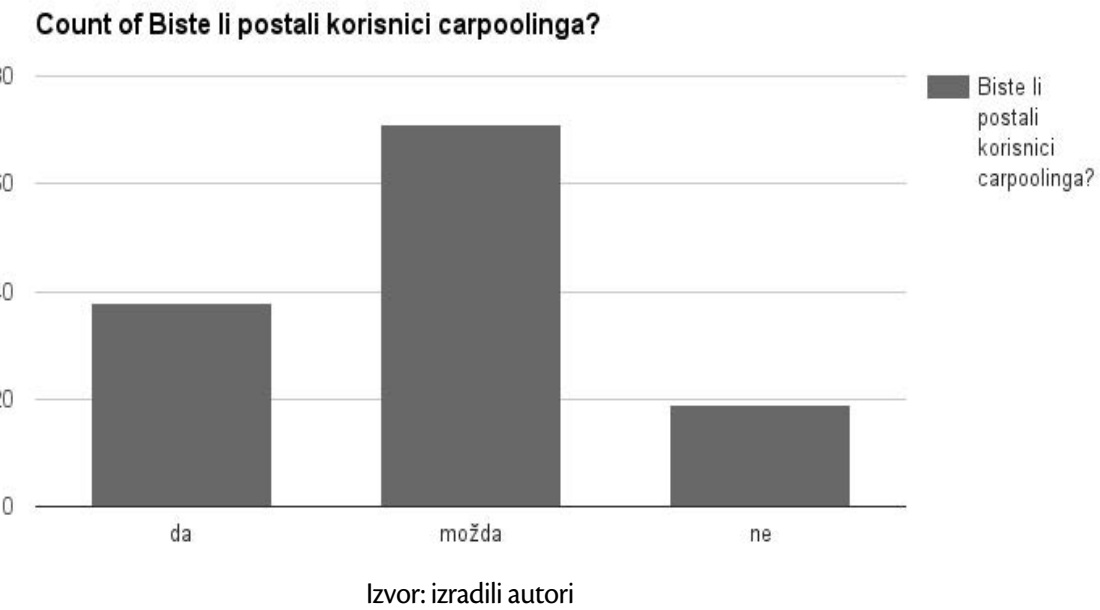

S druge strane stav ispitanika koji su iskazali potencijalnu namjeru korištenje ove usluge u budućnosti pokazuje da strah od vožnje s neznancima nije sveprisutan. Na pitanje s kime bi bili spremni dijeliti vožnju (samo poznanici ili neovisno o prethodnom poznanstvu) podjednak je broj onih koji bi vožnju dijelili samo s poznanicima i onih koji bi suputnike/vozača pronalazili neovisno o prethodnom poznanstvu (grafikon 6). Isto tako, potrebno je uzeti u obzir da su spomenuti stavovi podložni promjenama, odnosno postoji mogućnost da bi se prilikom korištenja te usluge i pozitivnih iskustava korisnika, određeni broj ispitanika s vožnji isključivo s poznanicima okrenuo dijeljenju vožnji neovisno o prethodnom poznanstvu.

Grafikon 6. Razdioba potencijalnih korisnika ovisno o voljnosti dijeljenja vožnji s njima poznatim ili nepoznatim osobama

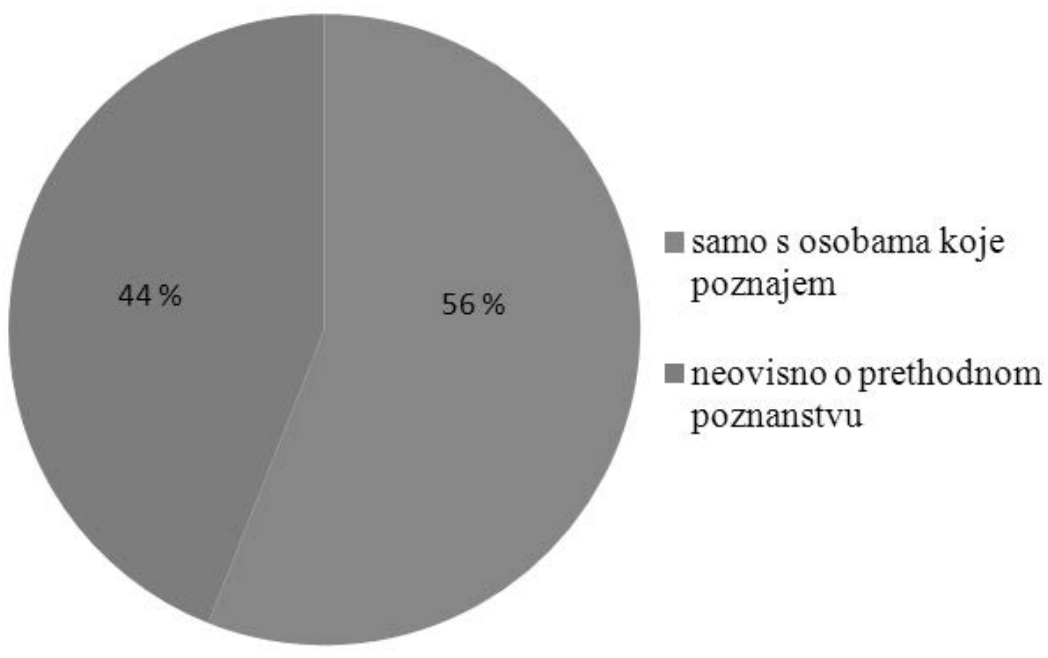

Izvor: izradili autori 
Strah i nelagoda pri pomisli na vožnju s nepoznatim ljudima opravdani su. Prilikom sjedanja u automobil s nepoznatom osobom potrebna je doza opreza. No, to nije nepremostiva prepreka za korištenje carpoolinga zato što svaki korisnik odabire hoće li vožnju dijeliti s neznancima ili isključivo s ljudima koje poznaje. Nadalje, carpooling organizacije taj problem olakšavaju putem registriranja korisnika te mogućnosti ocjenjivanja vozača i ostavljanja pozitivnih i negativnih komentara.

Usprkos obrazloženom strahu, najveći broj ispitanika (72 (55,8 \%)) na pitanje bi li postali korisnici carpoolinga odgovorilo je - možda. To je skupina na koju se treba fokusirati te ih različitim mjerama poticaja ili boljim informiranjem o načinu funkcioniranja i njegovim prednostima potaknuti na korištenje carpoolinga. U tom cilju nužno je razumjeti i razloge zbog kojih bi ispitanici bili spremni koristiti ovu uslugu (grafikon 7). Najvećem dijelu ispitanika primarni razlozi zbog kojih bi možda ili sigurno koristili carpooling su, očekivano, manji troškovi (48 od 110 ispitanika ili 43,6 \%) te fleksibilnost u odnosu na druge opcije prijevoza (36 ispitanika (32,7\%)). Iz ovih odgovora ponovno je vidljivo da je vodeći razlog korištenja carpoolinga financijska isplativost. Fleksibilnost u odnosu na druge opcije prijevoza također ima značajnu ulogu s obzirom na to da postoji mogućnost dogovora suputnika oko različitih detalja kao što su vrijeme i mjesto polaska, te ako se putuje na isto odredište, tzv. door to door prijevoz. Ipak, sustav carpooling nije u potpunosti fleksibilan te ne omogućuje promjenu željene destinacije tijekom putovanja. Razina fleksibilnosti zapravo ovisi o samim putnicima i njihovoj sklonosti dogovoru.

Grafikon 7. Razlozi korištenja carpoolinga

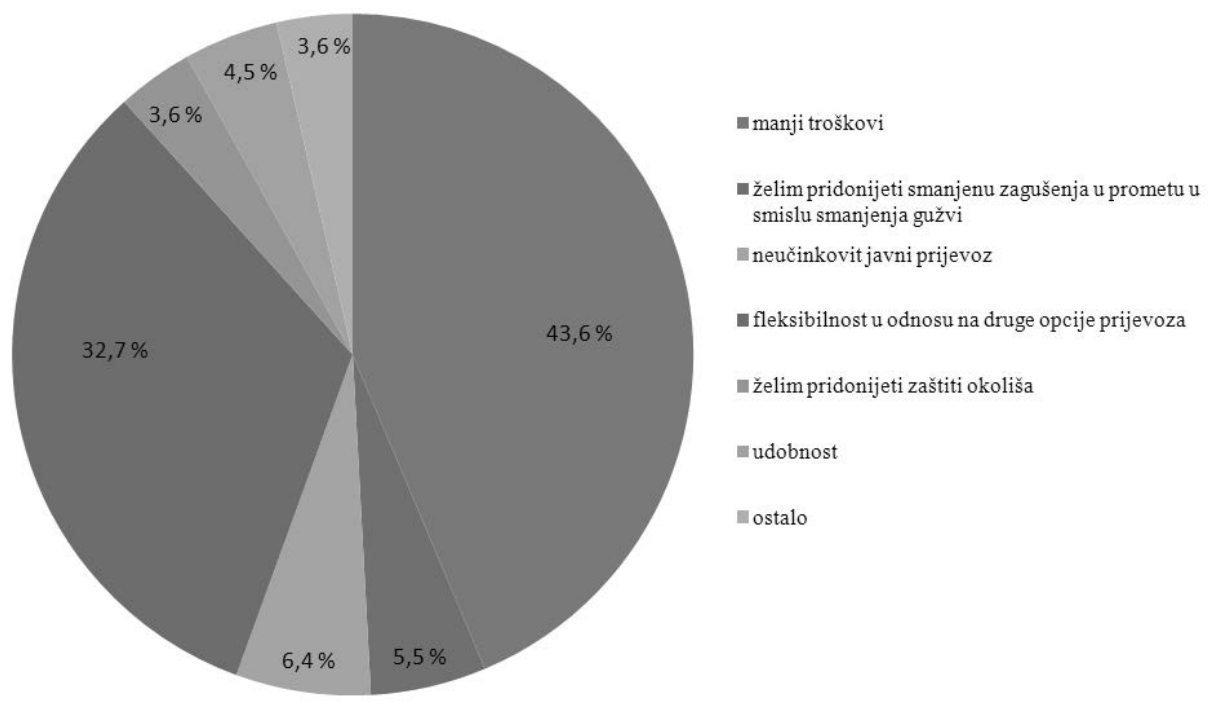

Izvor: izradili autori

Činjenica kako nekvalitetan javni prijevoz nije primaran razlog ohrabruje, naime, samo 7 ispitanika (6,4 \%) navodi neučinkovit javni prijevoz kao razlog, a isto tako relativno mali postotak ispitanika (5 ispitanika, 4,5 \%) vidi udobnost kao važan čimbenik korištenja carpoolinga. Prema tome, vidljiv je određeni potencijal i u ukupnom unaprjeđenju mobilnosti i smanjenju negativnih posljedica 
korištenja automobila makar kroz povećanje prosječnog broja putnika u njemu. Mora se priznati određena ekološka neosviještenost jer se najmanje ispitanika ( 4 ispitanika, 3,6 \%) izjasnilo kako bi im primaran razlog korištenja carpoolinga bio doprinos zaštiti okoliša). lako su gužve u prometu, posebice $u$ većim gradovima, značajan problem $s$ kojim se svi sudionici u prometu susreću, a posljedica su prevelikog broja vozila na cesti, tek 6 ispitanika (5,5\%) okrenulo bi se carpoolingu i na taj način dalo svoj doprinos njegovu smanjenju. $U$ analizi grafikona 7 važno je naglasiti da su ispitanici od ponuđenih odgovora mogli odabrati samo jedan, tj. osnovni razlog korištenja carpoolinga. U praksi je, naravno, moguće više odgovora, odnosno odluka o korištenju predstavlja kombinaciju više elemenata. Sve u svemu, neovisno o razlogu, korištenje carpoolinga pozitivno utječe na naš budžet, ono omogućuje veću mobilnost (zbog manjih gužvi), štiti okoliš, a samim time i generalno povećava kvalitetu života.

Iz grafikona 8, odnosno činjenice da je 16 od 54 ispitanika $(29,6 \%)$ sa samostalne vožnje prešlo na carpooling, vidljiv je izravan utjecaj na redukciju broja automobila na cesti. Mora se, međutim, priznati kako ipak većina korisnika na carpooling prelazi nakon korištenja usluga javnog prijevoza (32 ispitanika, odnosno 59,3 \%), ali to ne mora nužno biti loše ako predstavlja zamjenu za visokosubvencionirane linije s malom potražnjom.

Grafikon 8. Način prijevoza aktualnih korisnika carpoolinga prije početka korištenja te usluge

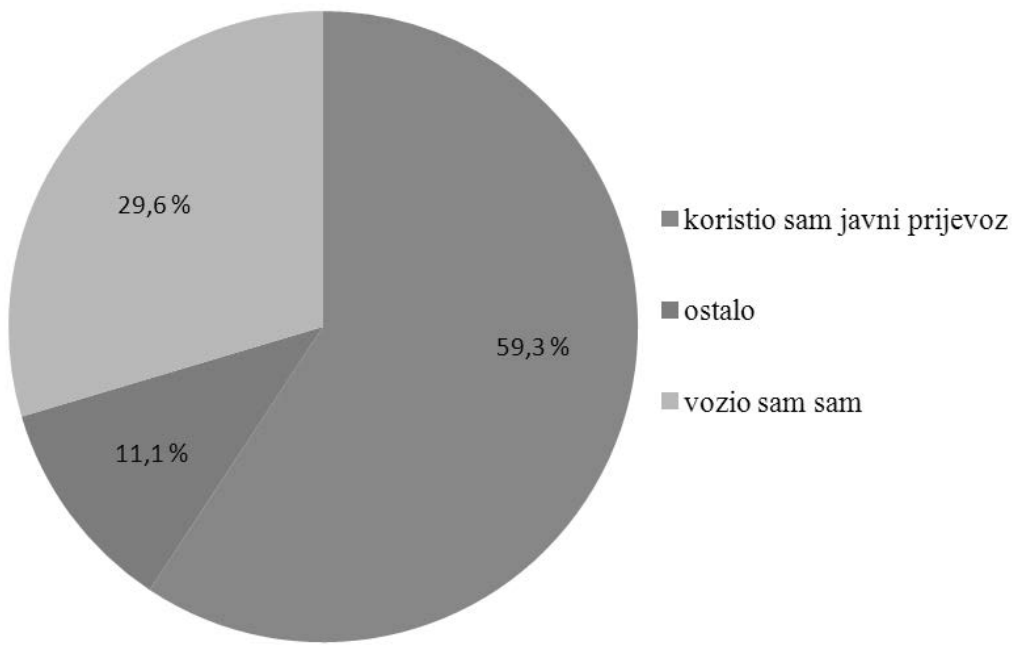

Izvor: izradili autori

Konačno, u cilju utvrđivanja mjera koje bi pridonijele daljnjem razvoju ove usluge te uvažavajući da se 38 ispitanika (29,5\%) izjasnilo da bi postali korisnici, a 72 (55,8\%) razmatra tu mogućnost, ispitanici su upitani o tome što bi moglo djelovati kao poticajna mjera. Najviše odgovora usmjereno je na smanjenje troškova prijevoza, što zapravo nije poticajna mjera, već prednost koju svako dijeljenje vožnji donosi. Nekolicina ispitanika izjasnila se da bi na njih kao poticajna mjera djelovala pozitivna iskustva korisnika. Uvažavajući potrebu poduzimanja određenih marketinških poteza u smislu reklamnih kampanja, koji bi za cilj imali predstavljanje carpoolinga široj populaciji, navedeno 


\section{S. Hirnig, L. Šikić, E. Gržin: Sustavi dijeljenja vožnji u funkciji smanjenja prometnih zagušenja... Zbornik Veleučilišta u Rijeci, Vol. 5 (2017), No. 1, pp. 107-124}

predstavlja značajan potencijal. Upravo zadovoljni korisnici carpoolinga mogu odigrati veliku ulogu u popularizaciji te usluge, jednim dijelom kroz reklamne kampanje i društvene mreže gdje bi mogli obrazložiti koji su njihovi razlozi korištenja, te drugim dijelom u neformalnoj komunikaciji s poznanicima. Putnici se često opiru nekom njima nedovoljno poznatom obliku prijevoza, no ako čuju pozitivna mišljenja nekoga iz njihove okoline lakše će se opredijeliti za uporabu.

U vrijeme provedbe ankete carsharing sustav u Republici Hrvatskoj postojao je samo u Koprivnici, a bio je namijenjen isključivo djelatnicima gradske uprave, gradskih poduzeća i ustanova. ${ }^{6} \mathrm{Na}$ pitanje bi li postali korisnici sustava carsharing ako bi postojala takva mogućnost, čak 125 ispitanika (68,3\%) odgovorilo je potvrdno (grafikon 9), što je izuzetno visok postotak, ako se uzme u obzir da se ispitanici nisu nikada susreli s tim oblikom prijevoza. Očekivano najviše zainteresirane za ovaj oblik prijevoza osobe su koje imaju vozačku dozvolu, ali nemaju automobile na raspolaganju. 16 ispitanika odgovorilo je da ima vozačku dozvolu, ali ne posjeduje osobni automobil, a od tih 16 samo jedan ispitanik ne bi postao korisnik carsharinga kad bi za to postojala mogućnost.

Grafikon 9. Udio broja potencijalnih korisnika sustava carsharing u ukupnom broju ispitanika

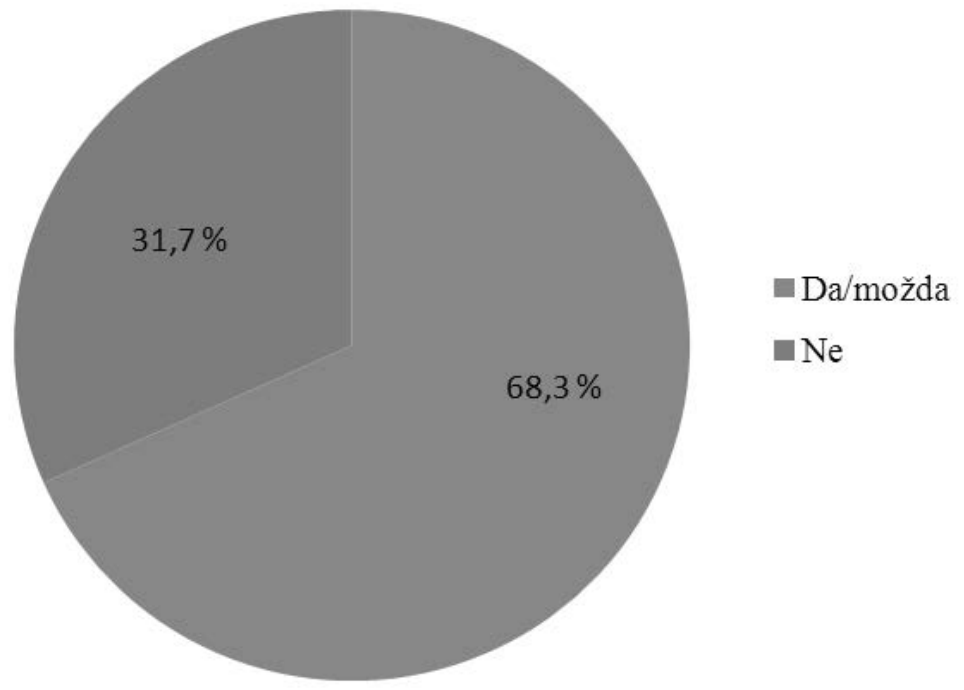

Izvor: izradili autori

6 Od lipnja 2016. u Zagrebu je dostupna usluga carsharinga pod nazivom Spin City koja je u samo šest dana od pokretanja privukla 180 korisnika (http://www.poslovni.hr/poduzetnik/u-6-dana-privukli-180-korisnika-314659, 16. 12. 2016.). Četiri mjeseca kasnije, usluge je koristilo više od 700 klijenata (http://autozona.rtl.hr/auti-i-ljudi/autii-ljudi/spin-city-zagreb/, 16. 12. 2016.). Spin City po cijelom gradu ima raspoređeno 10 automobila na električni i 20 na benzinski pogon. Najbliže slobodno vozilo pronalazi se putem aplikacije na pametnom telefonu koja nudi prikaz slobodnih vozila na karti, ali i mogućnost otključavanja vozila. Osim pomoću aplikacije, vozilo se može otključati i pametnom karticom Spin Cityja. U cijenu usluge uključeno je: korištenje vozila, gorivo, parkiranje, osiguranje i održavanje. Nakon završetka vožnje na putnom računalu u vozilu korisnik odabire opciju "završi moju vožnju" te izlazi iz vozila i zaključava ga opet pomoću pametne aplikacije ili pametne kartice (http://www.spincity.hr/kakokoristiti-spin-city/, 16. 12. 2016.). 


\section{ZAKLJUČAK}

Do pojave osobnih automobila veliki gradovi razvijenog svijeta funkcionirali su gotovo isključivo zahvaljujući javnom gradskom prometu koji je osiguravao mobilnost stanovnika. Osobna vozila u početku su samo povećala mobilnost jer su na neki način dopunjavala postojeći prometni sustav i to prvenstveno ograničenog imućnijeg sloja stanovništva. Kasnijom masovnom serijskom proizvodnjom automobili postaju dostupni svima. Danas velika većina vozača osobni automobil smatra nezamjenjivim sredstvom prometa. Posljedica ovakvog pristupa je prevelika ovisnost o automobilu, zagušenje prometa, zagađenje okoliša, ugrožena sigurnost i, generalno gledajući, smanjena kvaliteta života u gradovima.

Rješenje navedenih problema ne može se potražiti isključivo kroz ograničenje uporabe automobila i/ili promicanje javnog gradskog prijevoza. Fleksibilnost u odabiru vremena i mjesta kretanja, odabiru rute, omogućavanju prijevoza „od vrata do vrata" te privatnost, prednosti su uporabe osobnog automobila te će oni teško ikada moći biti u potpunosti supstituirani nekim oblikom javnog prijevoza. Uvođenje sustava dijeljena vožnji osigurava racionalniju upotrebu automobila uz zadržavanje svih prednosti koje takvo prijevozno sredstvo nudi.

Proučavajući sustave carpoolinga i carsharinga kao oblike dijeljenja automobila i prednosti koje oni donose neminovno se nameće pitanje njihovog intenzivnijeg razvoja u Republici Hrvatskoj. Rezultati provedenog istraživanja pokazuju da je u Republici Hrvatskoj carpooling uspješno zaživio i prakticira ga već relativno velik broj putnika, posebice mlađih, ali i veliki potencijal daljnjeg razvoja. Naime 110 od 129 ispitanika (85,2 \%) koji nisu nikada koristili carpooling iskazali su interes za njegovim korištenjem. Najvećem dijelu ispitanika primarni razlozi zbog kojih bi koristili carpooling su, očekivano, manji troškovi (48 ispitanika, 43,6\%) te fleksibilnost u odnosu na druge opcije prijevoza (36 ispitanik, 32,7 \%).

Utjecaj na javni prijevoz dvojben je i potrebno ga je dodatno istražiti. Širi društveni ciljevi razvoja ove usluge neće biti ostvareni ako ona privuče korisnike javnog prijevoza, a, nažalost, većina ispitanika se na carpooling odlučila upravo nakon korištenja usluga javnog prijevoza (32 od ukupno 54 ispitanika, $59,3 \%)$. S druge strane, samo 7 od 110 ispitanika (6,4 \%) navodi neučinkovit javni prijevoz kao razlog zbog kojeg bi upotrijebili carpooling uslugu, što ohrabruje jer ova supstitucija ne mora nužno biti loša ako predstavlja zamjenu za visoko subvencionirane linije s malom potražnjom. Ipak, činjenica da je 16 ispitanika (29,6\%) sa samostalne vožnje prešlo na carpooling pokazuje izravan utjecaj na redukciju broja automobila na cesti.

S druge strane, uočen je i značajan potencijal za uvođenje sustava carsharing u Republici Hrvatskoj jer se čak 125 ispitanika $(68,1 \%)$ izjasnilo kao potencijalni korisnici. Očekivano su najviše zainteresirane za ovaj oblik prijevoza osobe koje imaju vozačku dozvolu, ali nemaju automobile na raspolaganju, no ovaj podatak treba uzeti s velikom rezervom jer se radi o iskustveno nepoznatoj usluzi za ispitanike, a što je važnije, nepoznatih atributa (npr. cijena) što može značajno iskriviti sliku i stavove. U svakom slučaju, dijeljenje vožnji zaživjelo je u Republici Hrvatskoj, posebice među mlađom populacijom, te posjeduje velik potencijal koji bi bilo oportuno iskoristiti.

Analiza različitih studija i provedeno istraživanje potvrđuje temeljnu hipotezu rada. Primjena usluga dijeljena vožnji potencijalno smanjuje broj vozila na cesti, dovodi do racionalnije uporabe automobila, 


\section{S. Hirnig, L. Šikić, E. Gržin: Sustavi dijeljenja vožnji u funkciji smanjenja prometnih zagušenja... Zbornik Veleučilišta u Rijeci, Vol. 5 (2017), No. 1, pp. 107-124}

čime se smanjuju negativni utjecaji njihovog pretjeranog korištenja, a da se značajno ne umanjuje mobilnost građana. URH postoji zamjetan potencijali interes za sustavima dijeljene vožnje teje potrebno poduzeti daljnje mjere za njegovu popularizaciju. Pritom se očekuje veće značenje carpoolinga zbog dostupnosti većem broju građana. $U$ tom kontekstu, a uvažavajući potrebu definiranja mjera poticanja, mora se uvažiti kako prema provedenoj anketi ekološka svijest ima nažalost vrlo mali potencijal jer se najmanje ispitanika (4 ispitanika, 3,6 \%) izjasnilo kako bi im primaran razlog korištenja carpoolinga bio doprinos zaštiti okoliša. S druge strane, uvažavanje uočene osnovne prepreke korištenju definira dodatne mogućnosti. Naime, vrlo visok postotak ispitanika koji su se izjasnili da ne bi postali korisnici carpoolinga osjeća nelagodu pri pomisli na vožnju s nepoznatim ljudima (14 od 19 ispitanika, 73,7 \%), a 62 do 110 potencijalnih korisnika (56 \%) dijelilo bi vožnju samo s poznanicima. Stoga registriranje i djelovanje specijaliziranih servisa koji pomoću mobilnih aplikacija, osim organizacije prijevoza, omogućuju registriranja korisnika te ocjenjivanje vozača i ostavljanje pozitivnih i negativnih komentara i dr., mogu značajno pridonijeti povećanju broja korisnika. Navedeno dokazuje činjenica kako je dio ispitanika naveo kako bi na njih kao poticajna mjera djelovala upravo pozitivna iskustva korisnika.

\section{LITERATURA}

Calvert, T., Chatterjee, K. (2016) „The EVIDENCE project: Measure no. 18 - New models of car use“, World Transport Policy and Practice, 22(1/2), p. 171-185

Cervero, R., Tsai, Y. (2004) „City Carshare in San Francisko, California, Second-year travel demand and car ownership impacts", Journal oft he transportation reserch Bord, 1887(1), p. 117-127

Chan, N., Shaheen, S. (2012) „Ridesharing in North America: Past, present and future“, Transport reviews, 32(1), p. 93-112.

Correia, G., Viagas, J. (2011) Carpooling and carpool clubs: Clarifying concepts and assessing value enhancement possibilities trough a Stated Preference web survey in Lisbon, Portugal, Transportation Resercha Patrt A, 45 81-90

Créno, L. (2014) User experience of Dynamic Carpooling: How to encourage drivers and passengers?, Congress on Automotive Electronic Systems, At Montrouge, France

Ecoplan (2012) Utvardering av effektsamband for bilpool, Trafikverket, Švedska

Handke, V., Jonuschat, H. (2013) Flexible Ridesharing, New Opportunities and Service Concepts for Sustainable Mobility, Springer

Katz, M. A. C. (2012) The German Automobile Industry and the Challenge of Global Competition, 16th Annual Conference of the European Business History Association: Business Enterprises and the Tensions between Local and Global, Paris

Martin, E., Shaheen, S. (2011) „Greenhouse gas emission impacts of carsharing in North America“, IEEE transactions on intelligent transportation systems, 12(4), p. 1074-186

Mohan, D. (2009) Moving from the 19th century to the 21st century concerns, 4th International Conference on Future Urban Transport - Access and Mobility for the Cities of Tomorrow, Göteborg, Sweden

Murray, G. et al. (2005) Car-Sharing: Where and How It Succeeds, Transportation Research Board Executive Committee

Pucher, J., Buehler, R. (2005) Transport Policy in Post-Communist Europe, in: Button, K., Hensher, D. (editors): Handbook of transport strategy, policy and institutions, Vol. 6., Elsevier Press

Ter Schure, J., Napolitan, F., Hutchinson, R. (2012) „Cumulative impacts of carsharing and unbundled parking on vechicle ownership and more choice", Journal oft he Transportation Reserch Bord, 2319(1), p. 96-101

Šikić, L. (2016) Razvoj sustava dijeljenja vožnji i vozila u Republici Hrvatskoj, završni rad, Rijeka: Veleučilište u Rijeci http://www.slug-lines.com/slugging/About_Slugging.asp (15. 12. 2016.)

http://ec.europa.eu/eurostat/statistics-explained/index.php/Passenger_transport_statistics (13. 1. 2017.) 
S. Hirnig, L. Šikić, E. Gržin: Sustavi dijeljenja vožnji u funkciji smanjenja prometnih zagušenja... Zbornik Veleučilišta u Rijeci, Vol. 5 (2017), No. 1, pp. 107-124

http://ec.europa.eu/eurostat/documents/3217494/7596823/KS-01-16-691-EN-N.pdf/0abf140c-ccc7-4a7f-b236682effcde10f (13. 1.2017.)

http://www.poslovni.hr/poduzetnik/u-6-dana-privukli-180-korisnika-314659 (16. 12. 2016.)

http://www.spincity.hr/kako-koristiti-spin-city/ (16.12. 2016.) 
Saša Hirnig ${ }^{1}$

Lea Šikić ${ }^{2}$

Erika Gržin ${ }^{3}$
Preliminary communication

UDC 656.021

656.022 .3

\title{
SYSTEMS OF SHARING CAR JOURNEYS WITH THE AIM OF REDUCING THE NUMBER OF TRAFFIC JAMS BY KEEPING THE ACHIEVED LEVEL OF POPULATION MOBILITY ${ }^{4}$
}

\begin{abstract}
Undisputable advantages of cars in terms of comfort and independence they offer, that is, flexibility of movement and the ability to adjust to needs of a particular user led to high-rate motorization and undesirable phenomenon of "car-dependent" societies. As a consequence, it is precisely due to high-level rate of usage of cars and related traffic jams that their abovementioned advantages are being lost accompanied with a number of other unfavorable effects. Traffic jams decrease the speed of movement of vehicles and lengthen the time of travelling, cause stress and nervousness among drivers, lower the safety of traffic and lead to the increase in noxious gas emission, that is, pollution of the environment. One of the ways to decrease the mentioned consequences is to use cars more rationally and that could be accomplished, among others, by applying the systems of sharing car journeys. The carpooling system functions according to the principle of mutual benefit for the driver and the passenger (it secures the decrease of expenses to the driver, and the passenger uses all the benefits of a car) and contributes to the increase of a number of passengers in a vehicle, whereas carsharing allows for the availability of a car journey to all people who have a driving license without the necessity to own a car. Therefore, these systems enable the reduction of a number of vehicles in traffic and, thus, decrease of all unfavorable effects, while keeping, almost entirely, all advantages of using a car. According to the study conducted in the Republic of Croatia, there is a significant interest in the usage of these systems, that is, services.
\end{abstract}

Keywords: carpooling, carsharing, sharing a car journey, mobility

M. Eng., Senior Lecturer, Polytechnic of Rijeka, Vukovarska 58, Rijeka, Croatia. E-mail: sasa.hirnig@veleri.hr Student, Polytechnic of Rijeka, Vukovarska 58, Rijeka, Croatia. E-mail: lea.sikic@veleri.hr Spec. Ing. Traff., Lecturer, Polytechnic of Rijeka, Vukovarska 58, Rijeka, Croatia. E-mail: egrzin@veleri.hr Received: 15 February 2017; Accepted: 31 March 2017 